3. Wilson-Costello D, Friedman $\mathrm{H}$, Minic $\mathrm{N}$ et al. mproved neurodevelopmental outcomes for extremely low birth weight infants in 2000-2002 Pediatrics 2007; 119: 37-45

4. Robertson CM, Watt MJ, Yasui Y. Changes in the prevalence of cerebral palsy for children born very prematurely within a population-based program over 30 years. JAMA 2007; 297: 2733-40.

5. Robertson CM, Watt MJ, Dinu IA. Outcomes for the extremely premature infant: what is new? And where are we going? Pediatr Neurol 2009; 40: 189-96.

6. Yeh TF, Lin YJ, Huang CC et al. Early dexamethasone therapy in preterm infants: a follow-up study. Pediatrics 1998: 101: E7.

7. Embleton NE, Pang N, Cooke RJ. Postnatal malnutrition and growth retardation: an inevitable consequence of current recommendations in preterm infants? Pediatrics 2001; 107: 270 -3.

8. Verder H, Bohlin K, Kamper J et al. Nasal CPAP and surfactant for treatment of respiratory distress syndrome and prevention of bronchopulmonary dysplasia. Acta Paediatr 2009; 98: $1400-8$

9. Saugstad OD. Is oxygen more toxic than currently believed? Pediatrics 2001; 108: 1203-5.

10. Geary C, Caskey M, Fonesca R et al. Decreased incidence of bronchopulmonary dysplasia after early management changes, including surfactant and nasal continuous positive airway pressure treatment at delivery, lowered oxygen saturation goals, and early amino acid administration: a historical cohort study. Pediatrics 2008; 121: 89-96.

11. Schmidt B, Roberts RS, Davis P et al: Caffeine for Apnea of Prematurity Trial Group. Long-term effects of caffeine therapy for apnea of prematurity. N Engl J Med 2007; 357: 1893-902.

12. Norges forskningsråd. Grenser for behandling av for tidlig fødte barn: konsensuskonferanse 24.-25 november 1998. Rapport nr. 13 fra Komiteen for medisinsk teknologivurdering. Oslo: Norges forsk ningsråd, Området for medisin og helse, 1999.

3. Saugstad OD. Hvor fort skal for tidlig fødte barn vokse? Tidsskr Nor Lægeforen 2004; 124: 615.

14. Blanco CL, Cornell JE, Ramamurthy RS et al. Two year follow-up study from: the effect of early and higher protein supplementation on prevention of hyperkalemia in extremely low birth weight (ELBW) infants. Abstrakt. Pediatric Academic Societies' Annual Meeting 2008. Pediatric Acade mic Societies' Abstract Archives 2000-2008 E-PAS2008: 5630. www.pas-meeting.org/ 2008\%20Honolulu/abstract archives.asp (25.11.2009)

Manuskriptet ble mottatt 30.9. 2009 og godkjent 29.10. 2009. Medisinsk redaktør Erlend Hem.

\title{
Angstens arkitektur
}

Illustrasjoner av bygninger kan være en måte å fremstille sinnsstemninger på. En tegning av et hus med lukket dør og mørke vinduer kan uttrykke bestemte følelser. Et annet eksempel på det samme er Giovanni Battista Piranesis fengsler.

Giovanni Battista Piranesi (1720-78) ble født i Venezia hvor han tidlig utviklet interesse for teaterdekorasjoner og arkitektur. Da han var i 20 -årene kom han for første gang til Roma, og her ble hans fantasi stimulert av byens gamle bygninger og ruiner. Han gikk i lære som grafiker og startet etter hvert sitt eget atelier. I løpet av kort tid begynte han å lage grafiske blad fra etsninger i metallplater. Dette var ikke en ny teknikk, men Piranesi utviklet den til et mesterskap (1). Samtidig kostet det ham helsen ved at han stadig inhalerte damp fra sterke syrer.

De mest kjente av Piranesis arbeider er en serie på ca. 16 kobberplater med tittelen Carceri d'Invenzione: imaginære fengsler. De ble laget i årene 1749-59. Motivene er store drømmeaktige og massive interiører. Arkitekturen er visuelt uklar og truende, med interne broer over dype avgrunner og bueganger av stein som ikke ser ut til å lede noe steds hen. Fordi byggverkene er vanskelige å fatte, fremstår de som skremmende. Hvem kan ha oppført noe slikt, og hvorfor? Spørsmålene blir mange. De få menneskene som er synlige, blir knuget av byggets dimensjoner. De har ingen kontakt med verdenen utenfor. Det antydes torturinstrumenter i form av tau, brønner med vann og svære taljer. I noen av interiørene er det røyk eller damp. Vi ser en elaborert meningsløshet som blir ekstra uhyggelig fordi konstruksjonene er så solide. Jeg opplever bildene som uttrykk for en eksistensiell angst og håpløshet. De vekker følelser som jeg vil tro få av oss helt klarer å unngå i livet.

Flere kunstnere er blitt influert av disse bildene, for eksempel Francisco Goya (1746-1828), Edvard Munch (1863-1949), og den belgiske surrealisten Frank Brangwyn (1867-1956). Piranesi har også inspirert tyske impresjonistiske filmskapere som Fritz Lang (1890-1976) med filmen Metropolis (1927) og senere Federico Fellinis (1920-93) Roma (1972) og Ridley Scotts (f. 1937) Alien (1979). Forfat- terne Samuel Taylor Coleridge (1722-1834), Thomas de Quincey (1785-1859), Franz Kafka (1883-1924), og Aldous Huxley (1894-1963) er også påvirket av Piranesi. Cellisten Yo-Yo Ma har spilt inn en DVD med Bachs suite nummer 6 under tittelen The sound of carceri. Innspillingen foregår inne i en datagenerert tredimensjonal gjenskapning av Piranesis fengsler. Forholdet mellom Bach og arkitektur utforskes på en suggererende måte.

Menneskenes hus representerer vanligvis trygghet og sikkerhet, enten det er steinalderhuler eller moderne boliger. Men når hus, trygghetens symbol, fremstilles som truende, kan de både utløse angst og symbolisere angst. Carceri d'Invenzione har i mer enn to hundre år vært opplevd som angstens arkitektur.

\section{Anton Hauge}

anthau@medisin.uio.no

Avdeling for fysiologi

Universitetet i Oslo

\section{Oppgitte interessekonflikter: Ingen}

\section{Litteratur}

1. Ficacci L. Giovanni Battista Piranesi. The etchings. Køln: Taschen, 2003.

Manuskriptet ble mottatt 25.4. 2009 og godkjent 26.9. 2009. Medisinsk redaktør Anne Gitte Hertzberg.

Giovanni Battista Piranesi: The drawbrigde. Plate VII fra The Carceri d'Invenzioni (Imaginary prisons). Eid av Wallraf-RichartzMuseum/Fondation Corboud Köln. Foto Rheinisches Bildarchiv Köln 
Figur fjernet av hensyn til opphavsrett.

Se artikkelens utgave på internett (html) eller papir for fullstendig versjon.

Tidsskrift for

Den norske legeforening 